\title{
TEMA DAJDALA IN IKARA V EVROPSKI KNJIŽEVNOSTI'
}

Ključne besede: tematologija, Dajdal, Ikar, evropska književnost, slovenska književnost, literarnozgodovinski pregled

\section{Uvod}

Dajdal in njegov sin Ikar sta junaka zgodbe iz grške antične mitologije. Ta obsega tako kozmološke mite o nastanku sveta, zgodbe, ki pojasnjujejo človekov položaj v svetu, pripovedi o bogovih, kot tudi sklop med seboj povezanih legend o različnih junakih. Ena takih legend vključuje lika Dajdala in Ikara.

Osnovo nam bo predstavljala grška mitološka zgodba, ki jo povzemamo po Robertu Gravesu, nato pa bomo sledili pojavljanju Dajdalove in Ikarove teme v evropski in slovenski književnosti po kronološkem zaporedju. Pri konkretnih delih nas bo zanimala navezava na mitološko zgodbo, odmiki od nje ter specifične interpretacije posameznih avtorjev. Predstavili bomo skupne značilnosti pri obravnavi mitološke teme znotraj posameznih literarnih obdobji ter podobnosti in razlike med avtorji, tudi kadar pripadajo različnim časovnim obdobjem.

Antične mitološke zgodbe in njeni junaki so se $\mathrm{v}$ teku časa $\mathrm{v}$ različnih besedilih prenašali iz generacije $\mathrm{v}$ generacijo, zato predstavljajo našo kulturno dediščino, del splošne evropske zavesti. Ker se mitologija vedno zno-

1 Besedilo je nastalo na podlagi diplomskega dela pod mentorstvom doc. dr. Toneta Smoleja na Oddelku za primerjalno književnost in literarno teorijo Filozofske fakultete. 
va pojavlja v imaginariju ljudi, ki pripadajo isti skupnosti, predstavlja eno od opornih točk, ki tej skupnosti zagotavljajo določeno kohezijo.

\section{Mitološka zgodba o Dajdalu in Ikaru}

Splošno znane antične mitološke zgodbe so pogosto pravzaprav skrajšane verzije sicer daljših in bolj kompleksnih zgodb. Robert Graves nam jih predstavi na način, da lahko ugotavljamo njihovo medsebojno prepletenost in variacije. Kot vire za predstavitev zgodbe o Dajdalu in Ikaru Graves navaja naslednje avtorje: Apolodor, Apolonij z Rodosa, Diodor s Sicilije, Higin, Izidor iz Sevilije, Ovidij, Pavzanij, Platon, Plinij, Plutarh in Vergilij. Kot svoj vir je torej uporabil tudi antično književnost, to pa pomeni, da pri teh avtorjih v nadaljevanju besedila še ne bomo mogli govoriti o odmikih od izvorne mitološke snovi. Opazno vlogo v Gravesovi predstavitvi mitološke zgodbe o Dajdalu in Ikaru ima Ovidijeva zgodba iz Metamorfoz, ki opisuje Dajdalovo iznajdbo kril, s pomočjo katerih sta s sinom Ikarom pobegnila kretskemu vladarju Minosu tako, da sta poletela prek morja, pri tem pa se je Ikar smrtno ponesrečil. V primerjavi $\mathrm{z}$ drugimi različicami zgodbe je imela Ovidijeva na kasnejšo evropsko književnost največji vpliv, in tako predstavlja osnovo za nadaljnje literarne upodobitve Dajdalovega in Ikarovega lika. Poleg te najbolj znane zgodbe, zlasti Dajdal nastopa v kompleksnem sklopu legend, ki se med seboj prepletajo in se tako navezuje še na številne druge mitološke like.

Dajdal (gr. Daidalos, lat. Daedalus) je bil izumitelj, graditelj in umetnik, po rodu iz atenske kraljeve hiše. Njegovo ime pomeni "premeteni«, "pametni« ali »iznajdljivi«. V antiki skoraj ni bilo velike iznajdbe, ki je ne bi pripisovali Dajdalu, njegovi kipi so bili videti kot živi. Nečak in učenec Talos, sin Dajdalove sestre Polikaste, pa ga je pri svojih dvanajstih letih v spretnostih že začel presegati. Izum žage je Talosu v Atenah prinesel veliko slavo, v Dajdalu pa je raslo nevzdržno ljubosumje, zato je nečaka pahnil v prepad s templja na Akropoli. Talosov duh je zletel v podobo jerebice, telo pa so pokopali tam, kjer je padel. Ko je njegova mati Polikasta ${ }^{2}$ izvedela za sinovo smrt, se je obesila. Dajdalovo dejanje ni ostalo prikrito in areopag ga

2 Drugo ime zanjo je tudi Perdiks, kar pomeni »jerebica«. 
je za umor kaznoval z izgnanstvom. Po pregonu se je zatekel v neko atiško mesto, nato pa pobegnil na Kreto v Knosos, kjer ga je kralj Minos ${ }^{3} \mathrm{z}$ veseljem sprejel kot veščega obrtnika. Na Kreti je nekaj časa užival čast in živel v miru, dokler ni kralj Minos ugotovil, da je on pomagal Pazifai, ${ }^{4}$ da se je združila s Pozejdonovim belim bikom ${ }^{5}$.

Minos je preročišče prosil za nasvet, kako bi lahko najbolje skril pošast, ki jo je rodila Pazifaa. Svetovano mu je bilo, naj ukaže Dajdalu zgraditi utrdbo v Knososu. Dajdal je palačo zgradil v obliki labirinta, ${ }^{6}$ kot zapleten splet hodnikov in sob. Minos je v središče labirinta zaprl Minotavra, kasneje pa tudi Dajdala skupaj z njegovim sinom Ikarom.

Pozejdonov beli bik je pobesnel in pustošil po Kreti, dokler ga ni Herakles ulovil in odvedel v Grčijo. Tam ga je Evristej posvetil Heri in spustil na svobodo. Ker Hera ni sprejela poklona, je bik divjal naprej in med potjo od Istmija do Maratona ubil na stotine ljudi, med njimi tudi Minosovega sina Adrogeja. Na Maratonovem polju ga je nato premagal Tezej.

Kot nadomestilo za sinovo smrt je Minos od Atencev vsakih devet let zahteval sedem mladeničev in sedem mladenk. $V$ kretskem labirintu jih je nato raztrgal Minotaver, pošast $z$ bikovo glavo. Ko je bil čas za novo pošiljko atenskih žrtev, se je Tezej prostovoljno javil in se z njimi odpeljal na Kreto.

Ariadna, Minosova in Pazifaina hči, se je zaljubila v Tezeja in mu obljubila svojo pomoč pri uboju Minotavra. Imela je Dajdalov čarobni klobčič in

3 Evropa je na Kreti Zevsu rodila sinove Minosa, Radamantisa in Sarpedona.

4 Pazifaa je bila Minosova žena, hči Helija in nimfe Krete.

5 Ko je Minos zasedel kretski prestol, se je zavezal, da bo Pozejdonu žrtvoval belega bika, ki je z morja prišel na obrežje Krete. Vendar je svojo obljubo prelomil in belega bika vključil v svoje črede, Pozejdonu pa žrtvoval drugega bika. Pozejdon se je nato Minosu maščeval tako, da je v njegovi ženi Pazifai vzbudil ljubezensko strast do belega bika. Pazifaa se je zaupala Dajdalu in ta ji je napravil votlo leseno kravo, jo prekril s kravjo kožo in v kopita skril kolesca. Kraljici je pokazal, kako naj se namesti v kravo, nato pa jo je odpeljal na pašnik, kjer so se pasle Minosove črede. Iz zveze med Pazifao in Pozejdonovim bikom se je rodil Minotaver, stvor $\mathrm{z}$ bikovo glavo in človeškim telesom.

6 Arthur Evans razlaga, da je bil Dvor v Knososu zgrajen v obliki dvorezne sekire (grško »labrys«), kot splet hodnikov in sob. Zato so atenski roparji, ko so zavzeli dvor, težko našli in ubili kralja. Na planem pred dvorcem pa je bilo tudi plesišče $\mathrm{z}$ vzorcem labirinta, ki so ga uporabljali za obredne igre $\mathrm{z}$ jerebicami. 
je vedela, kako lahko vstopi in izstopi iz labirinta: konec vrvice je potrebno pritrditi pri vhodnih vratih na nadpražnik, klobčič se nato kotali in odvija po zavitih hodnikih do najglobljega mesta, kjer prebiva Minotaver. Tako je tudi Tezej z Ariadnino pomočjo prišel do Minotavra, ga ubil in z navijanjem niti na klobčič našel pot nazaj ven.

Vse različice mita so enotne v tem, da je Minos Dajdala skupaj z njegovim sinom Ikarom ${ }^{7}$ zaprl v labirint, ni pa povsem jasno, iz katerega razloga ju je zaprl. Graves navaja, da zato, ker je Dajdal pomagal Pazifai pri združitvi z belim bikom (Graves, 1990, 271), nekateri drugi avtorji (npr. Peyronie, 1992, 266) pa kot razlog za Minosov srd navajajo Dajdalovo pomoč Tezeju, s tem da je Ariadni razkril skrivnost, kako je možno najti pot iz labirinta.

Ker je Minos nadziral vsa pristanišča, se je Dajdal pri pobegu s Krete odločil za pot po zraku ter $\mathrm{v}$ ta namen sebi in sinu Ikaru naredil krila. ${ }^{8}$ Bočna peresa je povezal skupaj, manjša pa zlepil z voskom. Ko je krila pričvrstil Ikaru, ga je s solzami v očeh posvaril: »Sin moj, opozarjam te, ne leti previsoko, da ti sonce ne stopi voska, in ne prenizko, da ti perja ne ovlaži morje.« Zatem je še sebi nadel krila in skupaj sta poletela. »Leti tesno za mano, ne skreni s poti!« mu je zadnjič zaklical. Ko sta letela nad Kreto, so ribiči, pastirji in orači, ki so ju videli, menili, da sta bogova.

Za sabo sta pustila Naksos, Delos in Paros in ko sta se jima z desne strani že kazala Lebintos in Kalmin, je Ikar nehal ubogati očetova navodila in se začel dvigati k soncu, navdušen nad vzponom, ki so mu ga omogočala velika in močna krila. Ko je Dajdal pogledal prek rame nazaj, za sabo ni več videl Ikara, pač pa le še raztreseno perje v valovih pod sabo. Toplota sonca je Ikaru stopila vosek, zato je padel v morje in se utopil. Dajdal je krožil na mestu, dokler truplo ni splavalo na površje. Nato ga je prenesel na bližnji otok, kjer ga je pokopal. Pri tem ga je s hrasta opazovala jerebica in veselo čivkala. To je bila duša sestre Polikaste, njen sin Talos pa je bil tako mašče-

7 Ikar (gr. Ikaros, lat. Icarus) pomeni »posvečen mesečevi boginji Kar«. Ikarova mati Navkrata je bila ena od Minosovih suženj, njeno ime pa pomeni »sila morja«.

8 Po nekaterih drugih variantah mita je Dajdal pobegnil s Krete z barko, ki mu jo je priskrbela Pazifaa, ter ni izumil kril, pač pa jadro. Ikar naj bi se utopil, ko se je barka prevrnila zaradi nepravilnega krmarjenja. 
van. Otok, na katerem je pokopan Ikar, se od tedaj imenuje Ikarija. Morje, ki ga obdaja, pa Ikarsko morje.

Dajdal je letel na zahod, dokler se ni pri Kumah blizu Neaplja odločil, da svoja krila posveti Apolonu. Bogu je v ta namen zgradil tempelj z zlato streho. Nato je obiskal Kamik na Siciliji, kjer ga je kralj Kokal gostoljubno sprejel. Tam je Dajdal sezidal mnogo lepih zgradb in med Siciljanci užival velik ugled. Minos je, v lovu na Dajdala, s svojo floto prišel tudi na Sicilijo, tam pa so ga umorile Kokalove hčere z vrelo vodo. Proti koncu svojega življenja se Dajdal preseli na Sardinijo, kjer je tudi ohranjenih mnogo njegovih del.

Iz predstavitve mitološke zgodbe izhaja, da sta Dajdal in Ikar vsak zase samostojni mitološki figuri, saj njuna skupna zgodba traja le kratek čas. Ta zgodba predstavlja osrednjo zgodbo v celotnem mitu, sestavljajo pa jo naslednji osnovni motivi: 1) oče in sin sta v ujetništvu na Kreti pri vladarju Minosu, 2) da bi lahko pobegnila, Dajdal izumi krila, 3) med poletom Ikar ne sledi očetu, preveč se približa soncu in zato umre, 4) Dajdal pokoplje svojega sina, ki posmrtni spomin dobi v imenu otoka in morja.

Ikar je prisoten le v osrednjem dogodku celotne mitološke zgodbe, glavno vlogo dobi v trenutku, ko se med poletom oddalji od očeta. V nasprotju s tem lahko Dajdalovo življenje spremljamo od mladosti v Atenah, kjer je bil cenjen obrtnik in umetnik, izgnanstva na Kreto, kjer je gradil labirint, njegovega poleta s sinom čez morje, bivanja na Siciliji in končnega odhoda na Sardinijo. Mitološka predzgodba ponuja tudi možen razlog za Ikarovo smrt - povračilo za krivdo, ki si jo je Dajdal nakopal z umorom nečaka. $\mathrm{Na}$ podlagi tega že v izvorni mitološki zgodbi lahko iščemo razloge za to, da ima kasneje v literaturi lik Dajdala osrednjo vlogo predvsem v delih, ki sodijo na področje pripovedništva, lik Ikara pa se kot motiv ali tema pojavlja predvsem v liriki.

\section{Tema mitološke zgodbe o Dajdalu in Ikaru skozi literarnozgodovinska obdobja}

Avtorji, ki so v svoja literarna dela vključevali mit o Dajdalu in Ikaru, so glede na zgodovinsko obdobje, v katerem so pisali, v njem odkrivali različne 
poudarke in dogodke različno interpretirali. Pri tem lahko za posamezna obdobja ugotavljamo skupne značilnosti v smislu, da poudarjajo specifične sestavine Dajdalove in Ikarove teme.

V antični književnosti večinoma še ne gre za odmike od mitološke zgodbe, saj jo lahko rekonstruiramo tudi na podlagi teh del. Figuri Dajdala in Ikara antični avtorji večinoma prikazujejo skupaj, v očetovsko - sinovskem odnosu. Dajdal je spreten umetnik s posebnimi sposobnostmi, zmožen napraviti tudi tako neverjetne stvari, kot so hodeči kipi in krila, ki omogočajo človeku polet. V življenju njegovega sina Ikara je pomemben en sam trenutek: previsok vzpon $\mathrm{k}$ soncu in strmoglavljenje v morje.

Prva lik Dajdala omenita Homer in Platon. Predstavita ga kot umetnika in spretnega rokodelca in sicer $\mathrm{z}$ njegovimi manj znanimi deli: Homer v XVIII. spevu Iliade poroča, da je Dajdal napravil na Kreti plesišče za Ariadno, v Platonovem dialogu Menon pa beremo, da je izdeloval kipe, ki niso bili mrtve podobe, pač pa so se lahko premikali kot živi ljudje. Kasneje Vergilij in Ovidij v svoja dela vključita tudi lik Ikara in poudarita odnos med očetom in sinom. Zlasti v Ovidijevih Metamorfozah gre za arhetipsko podobo odnosa med očetom in sinom: Ikar s svojim igranjem moti očeta pri izdelovanju kril, preden poletita, daje oče Ikaru nasvete in priporočila o letenju, vendar jih ta kasneje ne upošteva, se odvrne od očeta in zato strmoglavi v morje ter umre. Ikarov padec je tako pri Ovidiju možno razumeti kot kazen za neubogljivost, vendar je po drugi strani Ikar prikazan kot heroj, ki si zasluži posmrtno slavo v imenu morja. Pojavi se tudi vprašanje očetove krivde pri sinovi smrti. Namreč, ko je Dajdal pokopaval sina na bližnjem otoku, je zraven žvrgolela jerebica. Iz predzgodbe pa vemo, da se je v jerebico spremenila duša Dajdalovega nečaka Talosa, ki ga je Dajdal pahnil z obzidja Akropole ter da je "jerebica« eno od imen Talosove matere. Tako se vzpostavi vzporednica med Ikarovim in Talesovim padcem in $\mathrm{v}$ tem smislu lahko Ikarovo smrt razumemo kot spravno dejanje za Dajdalov umor Talosa. Še pred Ovidijem tudi Vergilij v Eneidi predstavi vprašanje očetove krivde pri sinovi smrti. Na Ikara se obrne v neposrednem nagovoru, ko pravi, da naj bi bila tudi njegova podoba upodobljena na vratih templja, ki ga je Dajdal posvetil Apolonu, vendar je očetu pri poskusu vključitve sinove podobe v umetnino dvakrat omahnila roka. Aurnhamer in Martin v spremni besedi k antologiji Mythos Ikarus ugotavljata možen 
dvojni pomen tega odlomka: očetu je roka lahko omahnila zaradi žalosti ob sinovi smrti, ki je ni mogel preprečiti ali pa se je ob tem počutil krivega. Izguba sina bi lahko predstavljala kazen za izum kril in polet z njimi, saj je pri tem šlo za delovanje proti naravi oz. za poseganje na področje bogov. V Ovidijevi Umetnosti ljubezni je, za razliko od Metamorfoz, odnos med očetom in sinom prikazan bolj enakopravno, saj sta načrtovanje in izvedba poleta skupna in sporazumna. Ovidij v tem delu ne odpira moralnih vprašanj krivde, ampak vzpostavi izvirno primerjavo z Amorjem in tako nakaže možno povezavo z ljubezensko tematiko. Kot sta Dajdal in Ikar na krilih pobegnila proč od vladarja Minosa, tako tudi krilatega Amorja ne ustavijo postavljene prepreke. Posebnost Petronijevega Satirikona je v tem, da Dajdalovo ime uporabi kot sinonim za iznajdljivost, in sicer v okoliščinah, ki nimajo nobene zveze z mitološko zgodbo. Dajdalovo ime namreč uporabi za domiselnega kuharja.

Srednjeveški avtorji se navezujejo na antične, zlasti na Ovidijevo zgodbo iz Metamorfoz, vendar Dajdalov in Ikarov polet postavijo v nov miselni okvir tako, da ga navežejo na moralistične interpretacije. Ikarovo figuro obravnavajo v povsem negativni luči. Njegov previsok vzpon jim predstavlja simbol napuha in ošabnosti. Za tipičen primer lahko navedemo Sebastiana Branta, ki Ikara primerja s Faetontom in oba označi kot norca, ki nista poslušala očetovih navodil in sta zato umrla. Primerjavo s Faetontom uporabi tudi Dante, pri katerem sicer ne najdemo moralnih poudarkov v povezavi z mitom, pač pa se na več mestih v Božanski komediji kot motiv pojavi Dajdalov in Ikarov polet s krili v pomenu izjemne sposobnosti in izumiteljstva.

Književniki renesanse in baroka dokončno opustijo moralistične srednjeveške interpretacije. Lik Ikara upodabljajo samostojno, neodvisno od njegovega očeta. Predstavljajo ga v vlogi heroja, pri čemer se še vedno navezujejo na Metamorfoze, vendar mu poleg tega pripišejo nov pomen $\mathrm{v}$ navezavi na idejo novoplatonične ljubezni. Tako je v sonetu italijanskega pesnika Sanazzara prikazan kot heroj, ki je zaradi svoje drznosti umrl ter si zasluži večno slavo v imenu morja. Podobno vlogo heroja ima tudi v Tansillovemu sonetu, kjer se lirski subjekt identificira s figuro Ikara. Vzpon $\mathrm{k}$ soncu metaforično predstavlja stremljenje po visoki ljubezni. Pri tem ne gre za ljubezen do kakšne konkretne osebe, pač pa za božansko popolnost. 
Predstavnik nemške baročne lirike E. Ch. Homburg lik Ikara uporabi za primerjavo z zaljubljencem: kot Ikar k soncu se vzpenja k lepoti ljubljene, njene oči ga do smrti ranijo, potopi se v morje solz in kot Ikar $\mathrm{v}$ tem morju umre.

V obdobju klasicizma in razsvetljenstva nismo našli vidnejših upodobitev Dajdalove in Ikarove teme. Lik Ikara tako srečamo spet šele v Goethejevem Faustu. V drugem delu Fausta, v zadnjem prizoru tretjega dejanja je podoba Ikara zajeta v liku Evforiona. Evforion je sin Helene in Fausta, ki se ne meni za svarila staršev. Ker ga utesnjuje življenje na tleh, se vzpenja vedno više po skalovju. Želi si poleteti, vendar v tem poskusu strmoglavi in umre. Na koncu odlomka zbor Evforiona preimenuje v Ikara. Dramski junak pooseblja poezijo in herojstvo, metaforično pa se navezuje tudi na lorda Byrona.

Dajdalova in Ikarova tema je nadalje opazno prisotna $\mathrm{v}$ delih pomembnih predstavnikov književnih smeri fin de siècla. V Baudelairovi pesmi z naslovom Ikarova tožba $a^{9}$ se lirski subjekt $z$ ljubeznijo do višine, s stremljenjem po vzvišenem, idealnem in $v$ končnem padcu $v$ brezno identificira $z$ mitološkim likom Ikara. Baudelairov odmik od antičnega mitskega vzorca se pokaže v zadnji kitici: medtem ko se je Ikarovo ime ohranilo v imenu morja, lirski subjekt zase vidi le praznino in izgubo imena po smrti. Podoba tako kaže modernega pesnika, ki se dvigne nad vsakdanje življenje, vendar mu to ne prinese izpolnitve, temveč razočaranje. V elementu identifikacije lirskega subjekta $\mathrm{z}$ likom Ikara je Baudelaire podoben predhodnim pesnikom iz obdobja renesanse, od njih pa se razlikuje v tematiki, ki ni več ljubezenska, pač pa življenjska refleksija. Poleg tega pri Baudelairu Ikar ne predstavlja heroja, čigar slava bi se ohranila še po njegovi smrti.

Stefan George je v svojem prevodu prej omenjene Baudelairove pesmi $\mathrm{v}$ zadnji kitici uporabil tretjo osebo ednine, namesto prve osebe, kot je v originalu. S tem odmikom od izvirnika, je izrazil tudi večjo distanco do antičnega mita. Še preden je prevedel Baudelairovo, pa je George napisal svojo lastno pesem, v kateri lirski subjekt nagovarja mitološki lik Ikara. V

9 V prevodu Jožeta Udoviča. V prevodu Marije Javoršek je naslov pesmi Ikarove tožbe. Originalen naslov se glasi Les Plaintes d'un Icare, kar bi lahko dobesedno prevedli kot »Tožbe nekega Ikara«. 
njej ustvarja empatično bližino tako, da razumevajoče gleda na Ikarovo željo po višini in presežnosti. Avtorjeva inovacija v obravnavi Ikarove teme je $\mathrm{v}$ tem, da Ikarov padec prikaže kot posledico erotičnega srečanja s soncem (»zaradi vročega poljuba sonca«).

Prve upodobitve Dajdalove in Ikarove teme v 20. stoletju najdemo pri D’Annunziu, ki Ikarov lik uporabi v več pesmih. D’Annunzio pri tem upošteva Ovidijeva dela, saj antičnega avtorja v eni od svojih pesmi celo citira $\mathrm{v}$ naslovu ${ }^{10}$. V pesmi L’ala sul mare ${ }^{11}$ pa je poleg Ikara omenjen tudi Dajdal. To je precejšnja novost, saj od obdobja renesanse do 20. stoletja najdemo precej pesniških del, ki upodabljajo lik Ikara, ob tem pa puščajo njegovega očeta Dajdala ob strani. V D’Annunzijevi pesmi ima Ikar še vedno glavno vlogo, vendar je Dajdalovi mitološki zgodbi posvečena skoraj celotna druga kitica. Predstavljen je kot tisti, ki je izdelal krila za Ikara in napravil umetno kravo. Ob tem se pojavi tema Dajdalove nemoralnosti, saj je kravi dodan pridevnik »sramotna«, poleg tega je navedeno tudi, da je bil Dajdal zaradi tega »bogokletnega dejanja « zaprt. Posredno je odgovoren za sinovo tragično smrt, saj mu je on napravil krila. Čeprav je Ikarov polet označen kot nor, ima v pesmi kljub temu pozitivno vrednost. V nasprotju z Dajdalom, lik Ikara s svojim pogumom predstavlja vzor, zato lirski subjekt v neposrednem nagovoru išče možne Ikarove naslednike.

Mlado generacijo ekspresionistov je prevzela ugotovitev, da Ikar ne postane slavljen umetnik zaradi kakšnega lastnega dela, pač pa zgolj zaradi svoje samouničevalne potrebe po intenzivnejšem občutenju. Zaradi razvoja modernih tehnik letenja so se futuristi v svojih pesmih o letenju radi navezovali na podobo Ikara. V literarnem opusu Gottfrieda Benna najdemo dve pesmi, ki upodabljata lik Ikara. $V$ obeh avtor izrazito spremeni antični mit. Iz njegovih fragmentov s principom montaže ustvari lasten ekspresionističen izraz za kritiko civilizacije. V pesmi Ikar, je ta za razliko od lirskega subjekta dvignjen nad nizko, umazano stvarnost in tudi ostane na višini.

V Joyceovem romanu Umetnikov mladostni portret se v evropski književnosti pojavi nova literarna podoba Dajdala. Glavni junak romana, Stephen

10 Gre za pesem Altivs egit iter. V Gantarjevem prevodu Metamorfoz se to v slovenščini glasi: "pot ubere v višino«.

11 Perut na morju 
Dedalus, si v času odraščanja za svojega duhovnega očeta izbere antični lik Dajdala. Ta mu predstavlja umetniškost in svobodo kot temelj zanjo. Zaradi predanosti ustvarjanju se Stephen Dedalus želi znebiti vseh družbenih spon, tako verskih in nacionalnih, kot tudi družinskih vezi. Istega literarnega junaka kasneje srečamo tudi v Joyceovem Uliksu. Tako kot v predhodnem romanu, je tudi v Uliksu že na prvih straneh poudarjena posebnost junakovega priimka, ki se nanaša na mitološko figuro. Na to nas opozorijo besede ene od romanesknih oseb: »Kakšno nemogoče ime imaš, starogrško." (Joyce, 1993, 8). Stephen Dedalus je v Uliksu mlad intelektualec z umetniškim talentom. Svoboda ustvarjanja mu pomeni največjo vrednoto. Vzporednice med njim in mitološkim Dajdalom lahko vlečemo na podlagi njune želje po svobodi, inteligence in umetniškosti, s svojim idealizmom pa Stephen Dedalus prevzema tudi značilnosti Ikarovega lika.

V književnosti po letu 1945 se začnejo pojavljati relativizacije mitološke zgodbe. Tako je lik Ikara upodobljen v pesmi Samomor Gerda Adloffa, kjer je prvi verz ${ }^{12}$ identičen kot pri G. Bennu. Ikarova tema je pri Adloffu upodobljena v svojih značilnih elementih: zaradi želje po presežnem, se je vosek stopil in je padel. Avtorjeva inovacija in s tem tudi odmik od antične zgodbe se vzpostavi na koncu pesmi z alternativno možnostjo, da bi bil Ikarov padec lahko tudi posledica nezmožnosti dviga.

V romanu Michela Ayrtona Graditelj labirinta je na način namišljene avtobiografske pripovedi predstavljena celotna Dajdalova življenjska zgodba, ki upošteva njene različne variante. Lik Ikara je prikazan skozi oči njegovega očeta. $\mathrm{V}$ predstavitvi odnosa med očetom in sinom se začrta tudi različnost njunih življenjskih načel, pri čemer Dajdal sledi racionalnosti, njegov sin Ikar pa si prizadeva postati heroj. Roman predstavlja dvoumnost različnih variant mitološke zgodbe, saj Dajdal bralcem sporoča, kaj se mu je v življenju res zgodilo. Mit ima v romanu po eni strani pomen neresnice. Ta pomen se očitno izrazi v Dajdalovem pogovoru z Endijem, ki kljub temu, da je bil priča dogodku na Akropoli, kasneje ni povsem prepričan, da ni Dajdal vrgel Talosa z obzidja. Dajdal ob tem zaključi, da tudi poznavanje resnice ne izključuje sprejetja izmišljene zgodbe. Poleg tega pa je mit pred-

12 »Da fiel er uns vor die Füße« (Padel nam je pred noge) 
stavljen tudi v funkciji politične oblasti. V tem smislu Minos pravi, da je za vladarja nujno, da ohranja mit.

V romanu Poslednji svet Christopha Ransmayrja je Ikar predstavljen kot ena od podob, ki jih odkriva Ovidijev prijatelj med iskanjem Metamorfoz ob Črnem morju. Med svojim bivanjem v obmorskih Tomih, glavni junak ugotavlja prepletenost mitoloških zgodb in usod tamkajšnjih prebivalcev. Tiste Ovidijeve zgodbe, ki jih Ransmayr uporabi za usode svojih literarnih junakov, so v romanu bolj natančno predstavljene, druge pa so omenjene le mimogrede. Ena takih obrobnih zgodb vključuje tudi lik Ikara - predstavlja bitje, ki je sposobno letenja, vendar pade in se utopi. Ovidijev prijatelj ga najde med podobami, ki jih na tapiserije tke gluhonema Arahna. ${ }^{13}$

Po pregledu literarnih upodobitev Dajdala in Ikara skozi zgodovinska obdobja evropske književnosti, lahko povzamemo, da so avtorji v antiki v mitološki zgodbi o Dajdalu in Ikaru večinoma poudarili odnos med očetom in sinom; v obdobju srednjega veka so v moralistični luči lik Ikara videli predvsem kot prispodobo za človeški napuh in ošabnost; $v$ renesansi pa je Ikar dobil vlogo heroja $\mathrm{v}$ pesmih $\mathrm{z}$ ljubezensko tematiko. $\mathrm{V}$ časovnem obdobju od Baudelaira do Joycea imata tako Ikar kot Dajdal predvsem pomen modernega umetnika, ki intenzivno premišljuje o življenjskih vprašanjih, po letu 1945 pa so opazne relativizacije mitološke zgodbe.

Ugotovimo lahko, da sta lika, tako kot v izvorni mitološki zgodbi, večinoma upodobljena samostojno, neodvisno drug od drugega. Kljub temu, da sta redko prikazana skupaj, pa se pogosto opredeljujeta prav prek razlike do drugega ali pa prevzemata lastnosti drugega mitološkega lika. Njuna različnost se kaže predvsem na dveh ravneh: 1) nasprotje med mladostjo in starostjo in 2) nasprotje med dvema ustvarjalnima principoma - pesništvom, kjer so v ospredju čustva in znanostjo, ki temelji na razumu. Generacijska razlika med mitološkima likoma vpliva na njune številne druge lastnosti, ki so jima jih pripisovali različni literarni avtorji. Tako se s figuro Ikara povezuje zanos, ambicioznost, pogum, vihravost, iracionalnost, včasih celo norost. Pogosto je predstavljen kot heroj in v povezavi s tematiko ljube-

13 Po mitološki zgodbi se je Arahna hvalila, da tke lepše in bolj umetelno kot sama boginja. Ker se je to izkazalo kot resnično, jo je Atena v jezi spremenila v pajka. 
zni. V sebi združuje ambivalenco: lahko je prevzetnež ali pa heroj. Za razliko od njega je njegov oče Dajdal izkušen obrtnik in umetnik. Predstavlja premišljenost, uravnoteženost in razum. Na to se navezuje tudi nasprotje v njuni ustvarjalnosti, ki se kaže v tem, da predstavlja Ikar nadpovprečnega, izjemnega posameznika, ki stremi po vzvišenem idealu in prav zaradi tega fizično propade. Pesniki se pogosto identificirajo s figuro Ikara. Dajdalova poudarjena lastnost je iznajdljivost. Zagovarja svobodo ustvarjanja in ob tem včasih zanemari moralna vprašanja, saj ne predvidi negativnih posledic svojih dejanj (v antičnem mitu s tem, ko izdela umetno kravo, povzroči rojstvo pošasti).

\section{Dajdalova in lkarova tema $\mathbf{v}$ slovenski književnosti}

Upodobitve Dajdalove in Ikarove teme smo pri slovenskih avtorjih našli v obdobju razsvetljenstva v pesmi Janeza Miheliča, nato v naslovu ene od Kosovelovih konstruktivističnih pesmi, kasneje pa v 80. letih pri Vladimirju Gajšku, Tonetu Pavčku, Cirilu Zlobcu in Dragu Jančarju, ki so v različne literarne žanre vključevali podobi mitoloških likov.

V svoji edini pesmi z naslovom Mila pesm katiro je J. M. $k$ hvali teh pregovorov pejl Mihelič Dajdala omenja kot tistega, ki je izumil krila ter našel pot iz labirinta. Na ta način mitološki lik uporabi za ponazoritev iznajdljivosti. Podoba antičnega junaka je uporabljena kot primera. Po domiselnosti in sposobnosti narediti na videz nemogoče stvari, je Dajdal primerjan s Pohlinom, ki je napisal slovnico kranjskega jezika.

Ena od pesmi Srečka Kosovela, ki jih je imenoval konstrukcije, je naslovljena z mitološkim junakom Ikarom: Kons. Ikarus. Anton Ocvirk podobo mitološkega lika $\mathrm{v}$ tej pesmi razlaga $\mathrm{z}$ besedami: »Pesnik je tu kakor bajeslovni letalec Ikar, ki je ušel iz labirinta praznih slepil, a je strmoglavil, ker se je dvignil previsoko, z vso silo v realnost naše takratne sedanjosti.« (Ocvirk, 1974, 615). V še neobjavljeni monografiji o Srečku Kosovelu pa Janez Vrečko poudarja, da je v ozadju te pesmi tudi filozofija slovenstva Klementa Juga kot slovenskega Ikara. V nasprotju z Jugom je večina Slovencev tiščala glavo v pesek ob potujčevanju Slovencev v tedanji Italiji. Jugov poznejši padec dejansko ni bil padec, saj je celotni generaciji zapustil dedišči- 
no, da je lahko presegala zgodovinske in politične možnosti. Sicer pa Vrečko poudarja, da je Ikarova tema pogosta $\mathrm{v}$ avantgardistični ustvarjalnosti, najznamenitejše udejanjenje je doživela $\mathrm{v}$ Tatlinovem Letalinu, kjer je šlo po Tatlinovih besedah za sanje, stare kot človeštvo. Ker je Letalin, sestavljen iz glagola »letati« in slikarjevega priimka, metaforično vseboval življenjsko in ustvarjalno biografijo, bi morda podobno zvezo našli tudi med konsi in Kosovelom. Ikarovo temo pa je po Vrečku najti tudi v Krleževi oznaki Chagallove umetnosti, ki ji jo je označil za »ikarske polete v prazno«. Kosovel je Krležo sproti prebiral in ga priporočal tudi prijateljem.

V romanu Vladimirja Gajška Ikarovo perje, ki je izšel leta 1980, je Ikar eno od nastopajočih bitji. Naslov romana avtor sam pojasni z besedami: »Ikarovo perje je pisateljsko perje, je neštevilo pisateljskih peres, ki premagujejo smrt. (Črnčič, 1986, 133). Ena od glavnih tem romana je nasprotovanje vsakršnemu vojskovanju, kar avtor v predgovoru tudi izrecno izrazi: »Pisano Ikarovo perje gre izpod mojega peresa v perje proti vsem zbesnelim bitkam, proti vojnam pa vojnim časom, ki so bili ali še bojo, ja, zoper vsakršno vojskovanje.« (Gajšek, 1980, 7) Dogajanje je postavljeno v čas po koncu sveta med stroje in duhove. Zunanji svet predstavlja večno vojskovanje, ki je samo sebi namen, notranji svet pa je blodnjak v podzemlju, kjer na invalidskem vozičku živi breznogec Veselonc. Spremljajo ga krilatec ptiček Ikar, šviglja Erinija, zarodek Jon, zvezdni pastir Vladimir in detožerec kramar Minotaver. Od vseh teh spremljevalcev je prav Ikar najbližji glavnemu junaku, morda predstavlja kar del njegovega jaza. Veselonc včasih sanja, da bo postal ptič Ikar in bo lahko letel. Letenje tu verjetno simbolizira željo glavnega junaka po svobodi. V povezavi z Ikarovim likom se v romanu poleg letenja pojavijo tudi asociacije na morje in sonce, kar se očitno navezuje na antični mit, nima pa nič skupnega $\mathrm{z}$ dejanskim krajem dogajanja $\mathrm{v}$ romanu. Značilni elementi Ikarove teme so zajeti tudi v naslednjih oznakah ptiča Ikara: »je šel dalj kot vsi«, »je malo čez les«, »neki duh živi v njem, čist ali zal duh«, (Gajšek, 1980, 170) »obrnil je vse narobe, samomor pa v smisel življenja» (Gajšek, 1980, 207)

Pavčkovo pesem Ikar najdemo v pesniški zbirki, ki je izšla leta $1983 \mathrm{z}$ naslovom Dediščina. Zbirka vključuje več pesniških ciklov, že po njihovih naslovih pa lahko razberemo, da jih povezuje tema odhajanja, minevanja in smrti. V ciklu Osmrtnice avtor upesnjuje bolečino ob smrti svojega sina. 
Pesem se na temo Ikara navezuje $\mathrm{v}$ več elementih: $\mathrm{z}$ belo barvo in sinjino neba je nakazan vzpon in idealnost, ki jo prelomi blisk. Temu sledita tema in rana $\mathrm{v}$ metaforičnem pomenu smrti, ki Ikara doleti na višku moči. Za razliko od izvorne mitološke zgodbe, pri Pavčku Ikar ne pade v morje, ampak v zemljo. S tem je podoba padca prikazana še bolj izrazito, saj je zemlja ustrezen nasprotni element neba. Tudi v zaključku Pavčkova pesem še vedno sledi antičnemu vzoru, saj s smrtjo Ikar ne utone v pozabo, pač pa tudi po smrti žari njegova veličina. Razliko od izvornega mita avtor vzpostavi s tem, da ne gre za posmrtno slavo heroja, ampak za individualni spomin, ki ga za umrlim ohranijo njegovi bližnji.

Ikarovo temo je literarno upodobil tudi Ciril Zlobec v pesniški zbirki Nove pesmi iz leta 1985. Pesniška zbirka v več ciklih obravnava teme ljubezni, družine, samote, Krasa. Cikel $V$ labirintu pa je v celoti posvečen mitološkim temam. Lirski subjekt pogosto govori v prvi osebi množine. $\mathrm{V}$ pesmih se po eni strani vzpostavlja identifikacija, po drugi pa različnost $\mathrm{z}$ mitološkimi liki. Pri tem množinski lirski subjekt $\mathrm{v}$ podobi sodobnega človeka prevzame le negativne vidike usod antičnih mitoloških junakov; tako na primer ne poznamo več prometejskega upora, dobro pa smo seznanjeni s kaznijo, ki nam je naložena. Avtor upesnjuje eksistencialne stiske sodobnega človeka, zaradi česar je prevladujoče občutje $\mathrm{v}$ pesmih pesimistično. V pesmi Z Ikarom okuženi se vzpostavlja podobnost sodobnega človeka $\mathrm{z}$ mitološkim likom na podlagi prastare človekove želje po letenju. Ta $\mathrm{v}$ povezavi z Ikarovo temo pri Zlobcu simbolizira željo po višinah, ki niso dovoljene. Vendar si za razliko od Ikara sodobni človek ne želi letenja zaradi hrepenenja po vrnitvi, pač pa le beži stran od znanega, ki ga utruja. Zlobec v tem elementu ne sledi niti izvorni mitološki zgodbi niti kasnejšim literarnim upodobitvam Ikarove teme, saj zanjo ni značilno hrepenenje po vrnitvi, pač pa po bližini s soncem, ki predstavlja ideal. Želja po vrnitvi oz. domotožje se na splošno povezuje le z Dajdalovim likom.

Drami Klementov padec in Dedalus Draga Jančarja sta v knjižni obliki izšli leta 1988. V navezavi na mitološko zgodbo o Dajdalu in Ikaru lahko glavnega dramskega junaka Klementa vzporejamo s figuro mitološkega Ikara, zgodbo drame Dedalus pa z mitološko zgodbo o Dajdalovi gradnji labirinta na Kreti. 
Podobnost med Ikarom in dramskim junakom Klementom, ki predstavlja tudi zgodovinsko osebo Klementa Juga, se kaže v življenjski filozofiji dramskega junaka, njegovem značaju in usodi. Klement je poln idealističnega zanosa, stremi po drugačnem, višjem, čistejšem življenju, po človekovih presežnih vrednostih. Zagovarja filozofijo tveganja in drznosti. S svojimi alpinističnimi podvigi se vzpenja nad povprečnost, ki jo prezira. Druge dramske osebe ga imajo za čudaka, pripisujejo mu pretiravanje. Profesor na primer pravi, da ga je obvladal domišljav duhovni zanos in obsedenost $\mathrm{z}$ veličino, vendar pa mu ob tem priznava tudi pogum (Jančar, 1988, 181). Umre mlad, na vrhuncu svojih moči. Klementova smrt pri drugih dramskih osebah sproži različne odzive. Nekateri menijo, da je umrl zaradi svoje nezmernosti in da je šel v smrt zavestno in namenoma, drugi pa ga začnejo častiti kot junaka in njegovo filozofijo priporočajo naslednjim generacijam. Jančar v osebi Klementa predstavi vse bistvene lastnosti Ikarove teme: mladost, zanos, pogum, iracionalnost, norost. Njegova smrt je dvoumna - lahko predstavlja kazen za previsoke ambicije ali pa tragičen padec pri iskanju popolnosti.

V drami Dedalus gre za aktualizacijo antične mitološke zgodbe. Zgodba o Dajdalovi gradnji labirinta na Kreti je literarno prenesena v sodoben prostor in čas. Tako kot mitološki Dajdal je tudi glavni junak Jančarjeve drame arhitekt, izumitelj in umetnik. Po naročilu oblasti gradi zapor, ki ga zasnuje v obliki labirinta, kasneje pa njega samega zaprejo vanj. Dogajanje $\mathrm{v}$ drami je postavljeno $\mathrm{v}$ čas po drugi svetovni vojni, ko se je uveljavil socialistični politični sistem. Morda lahko v glavnem dramskem junaku Dedalu in njegovi gradnji zapora vidimo realno zgodovinsko referenco v osebi Milana Apiha in gradnji novih zaporov po naročilu Centralnega komiteja v Beogradu. Tako kot mitološkega Dajdala, tudi junaka drame Dedalus bistveno opredeljujejo njegova iznajdljivost, veselje pri reševanju tehničnih problemov, razumski pristop in umetniška ustvarjalnost. Pri obeh likih predstavlja gradnja zapora $\mathrm{v}$ obliki labirinta njuno glavno življenjsko delo. Jančarjeva drama se torej tesno navezuje na tisti del mitološke zgodbe, ki opisuje Dajdalovo življenje na Kreti. Od izvornega mita se razlikuje v tem, da ne vključi figure Dajdalovega sina Ikarja ter njunega skupnega pobega iz zapora s pomočjo kril. Kljub temu Ikar v drami ni povsem odsoten. Dedal ga omeni v svojem sklepnem monologu, poleg tega lahko nekatere njegove značilne poteze opazimo pri predstavljenih značilnostih komunističnega sistema. Tiste dramske osebe, ki predstavljajo prave privržence socialistični 
ideologiji tako preveva občutje zanosa, menijo, da so na vrhu zgodovine. Zaradi pretiranega zanosa ne upoštevajo stvarnih argumentov razuma, ki ga pooseblja Dedalov pomočnik Hutter z opozarjanjem na problem statike. Polom veličastne zgradbe kot metafore za neuspeh političnega sistema, lahko vzporejamo z mitološkim Ikarom, ki je strmoglavil zaradi svojih previsokih ambicij. In tako kot je Ikar postal heroj, čeprav njegov poskus ni uspel, so tudi glavni predstavniki oblasti v drami mnenja, da so heroji, čeprav se projekt ni posrečil.

Jančarjev roman Graditelj je izšel leta 2006 za mednarodno zbirko Miti. V njem se je avtor ponovno lotil snovi, ki jo je obravnaval že v svoji predhodni drami Dedalus. V primerjavi z dramo, so v romanu vzporednice z grško mitološko zgodbo še bolj jasno in nedvoumno začrtane. Avtorju to omogoča zlasti tehnika okvirne zgodbe, v kateri glavni junak, arhitekt Pavel Areh opisuje svojo življenjsko izkušnjo. Poleg navezave na mitološko zgodbo o Dajdalu, ki je uporabljena kot primerjava za življenjsko zgodbo literarnega junaka, se skozi celoten roman vlečejo tudi vzporednice med antično mitologijo na splošno in mitskimi strukturami socialističnega sistema v konkretnem zgodovinskem obdobju nekdanje Jugoslavije. Pri tem je avtor na nekaterih mestih zelo konkreten. Tako na primer mitološki lik Minosa identificira z zgodovinsko osebo Tita. »In kje je tu Minos? Marek je samo dvorjan in izvrševalec. Minos je na jadranskih otokih znamenitega imena Brioni. Morda se na svoji ladji znamenitega imena Galeb pelje mimo otoka strašnega imena Goli.« (Jančar, 2006, 117-18) Posebnost Jančarjevega romana Graditelj je torej v tem, da avtor skozi zgodbo vzpostavi povezavo med antično mitologijo ter socialistično ideologijo. Na literarni način prikaže, da gre pri obeh pojavih za vsiljene in na specifičen način preoblikovane predstave o realnosti, ki jih ima večina ljudi.

V slovenski književnosti se upodobitve Dajdalove in Ikarove teme pojavljajo zlasti pri avtorjih, ki so pisali v 80 . letih 20. stoletja. Gajšek prek asociacij našteje večino znanih interpretacij Ikarove teme. Pavček se na Ikarov lik naveže s temo smrti in spominom na pokojnega sina. Pri Zlobcu so predstavljene identifikacije sodobnega človeka $\mathrm{z}$ negativnimi vidiki usod mitoloških junakov. Jančar Dajdalovo in Ikarovo temo obravnava v dveh dramah in romanu. Značilno zanj je, da se $\mathrm{z}$ obema antičnima likoma navezuje na dejansko obstoječo zgodovinsko osebo in čas. 


\section{Zaključek}

Antične mitološke zgodbe so nastajale v času, ko Grki še niso uporabljali pisave, zato jim težko iščemo izvor oz. avtorja. Ohranjal jih je družbeni spomin, ki jih je sčasoma tudi preoblikoval, in tako je nastalo več variant. Kasneje so jih zapisali v obliki literarnega ali zgodovinskega teksta, s čimer so mitološke vsebine dobile jasno strukturo zgodbe, tako pa postale še zlasti primerne za nadaljnje vključevanje v literarno umetnost. Mitološka snov zajema arhetipske človeške značaje in situacije, saj obravnava večna vprašanja človeškega bivanja. To pomeni, da je mitološke zgodbe in njene junake moč aktualizirati $\mathrm{v}$ različnih časih, $\mathrm{z}$ različnimi pogledi. K različnim interpretacijam in identifikacijam pa napeljuje večpomenskost, ki je prisotna že v samem temelju teh zgodb. Ker se le redko lahko dokopljemo do izvirnika, se bolj osredotočamo na manifestacije mitoloških tem $\mathrm{v}$ posameznih literarnozgodovinskih obdobjih. Moč mita je namreč ravno v tem, da se v teku stoletji spreminja, ne da bi nehal biti prepoznaven.

Pri pregledu Dajdalove in Ikarove teme v evropski književnosti smo predstavili zlasti skupne značilnosti znotraj posameznih literarnih obdobji. V splošnem je Dajdal večinoma predstavljen kot obrtnik in umetnik, njegova najpomembnejša lastnost je iznajdljivost. Predan je ustvarjanju, ob tem pa po nekaterih interpretacijah zanemari moralna vprašanja. Na lik Ikarja se pogosto veže občutje zanosa, predstavljen je ali kot prevzetnež, ki ga je doletela pravična kazen za previsoke ambicije, ali kot heroj, ki je iskal popolnost in padel kot žrtev lastne drznosti. Odnos med obema mitološkima likoma lahko vidimo v luči generacijske razlike med očetom in sinom, kot nasprotje med razumom in navdihom, ali pa razumemo Dajdala v vlogi klasičnega umetnika, veščega, zrelega rokodelca, medtem ko nam Ikar, kot njegovo nasprotje, lahko predstavlja simbol romantičnega umetnika, sicer nespornega naslednika klasičnega umetnika, vendar vihrave, strastne in uporniške narave, ki ga kljubovanje konvencijam privede do samouničenja. Literarna podoba Ikara je izrazito prisotna v lirskih delih, Dajdalova podoba pa zlasti v pripovedništvu. 


\section{VIRI}

Alighieri, D., Božanska komedija, Celje, 2005.

Ayrton, M., The Maze Maker, New York, Chicago, San Francisco, 1967.

Baudelaire, C., Rože zla, Ljubljana, 2004.

Baudelaire, C., Charles Baudelaire, Ljubljana, 1998.

Benn, G., Benn, Ljubljana, 1976.

Gajšek, V., Ikarovo perje. Roman o čudežih in čudakih, Maribor, 1980.

Goethe, J. W., Faust. Drugi del, odlomki, Ljubljana, 1996.

Homer, Iliada, XVIII, Ljubljana, 1978.

Joyce, J., Umetnikov mladostni portret, Ljubljana, 1987.

Joyce, J., Ulikses, Ljubljana, 1993.

Jančar, D., Tri igre, Ljubljana, 1988.

Jančar, D., Graditelj (mit o Dedalu), Ljubljana, 2006.

Kosovel, S., Zbrano delo, Druga knjiga. Ljubljana, 1974.

Mihelič, J., Mila pesm katiro je J. M. k hvali teh pregovorov pejl, v: Pisanice 1779-1782 (ur. Legiša, L.), Ljubljana, 1977.

Ovidij, N. P., Metamorfoze: izbor. Ljubljana, 1977.

Ovidij, N. P., Umetnost ljubezni = Ars amatoria, Ljubljana, 2002.

Pavček, T., Dediščina, Ljubljana, 1983.

Petronij, A. T., Satirikon, Ljubljana, 2006.

Platon, Zbrana dela I., Celje, 2004.

Ransmayr, C., Poslednji svet. Z Ovidijevim repertoarjem, Ljubljana, 1990.

Vergilij, M. P., Eneida, VI, Ljubljana, 1978.

Zlobec, C., Nove pesmi, Ljubljana, 1985. 


\section{LITERATURA}

Aubelj, B., Antična imena po slovensko, Ljubljana, 1997.

Aurnhamer, A. in Martin D., Mythos Ikarus, 2003.

Berger, A., O drsnosti in vzdržnosti, v: Gledališki list SNG Drama, Ljubljana, $1987 / 88$.

Chevrel, Y., Literarne raziskave in Stroffgeschichte: komparativistični predlogi, v: Tematologija. Izbrana poglavja (ur. Smolej, T.), Ljubljana, 2007.

Črnčič, I., Vosek Ikarovega perja - pogovor z Vladimirom Gajškom o romanu Ikarovo perje, Dialogi, št. 8-9, 1986, str. 133.

Graves, R., The Greek myths, Harmondsworth, 1969.

Graves, R., Grčki mitovi. Beograd, 1990.

Inkret, A., O mrtvem zmagovalcu ali njena nesrečna ljubezen, v: Jančar, D., Tri igre, Ljubljana, 1988.

Kos, J., Joyceov roman o umetnikovi mladosti, v: James, J., Umetnikov mladostni portret, Ljubljana, 1987.

Legiša, L., Pisanice 1779-1782, Ljubljana, 1977.

Novak, B. A., Labirint brez minotavra, v: Gledališki list SNG Drama, Ljubljana, 1987/88.

Ocvirk, A., Opombe, v: Kosovel, S., Zbrano delo. Druga knjiga, Ljubljana, 1974.

Partljič, T., Kako je Ikaru na tleh?, v: Gledališki list MGL, Ljubljana, 1988/89.

Peyronie, A., Daedalus, v: Companion to Literary Myths, Heroes and Archetypes (ur. Brunel P.), London, New York, 1992.

Samide, I., Topografija Faustovih svetov, v: Goethe, J. W., Faust. Drugi del, odlomki, Ljubljana, 1996.

Švajncer, M., Ciril Zlobec - pesnik ljubezni, Ljubljana, 1995.

Velikonja, M., Nedokončane zgodbe - sodobna politična mitologija, v: $\check{C} a-$ sopis za kritiko znanosti, let. 22, 1994, str. 153-179. 
Vincentič, M., Tone Pavček: Dediščina, v: Dialogi, 1984, str. 65.

Vouk, E., Opombe, v: Goethe, J.W., Faust. Drugi del, odlomki, Ljubljana, 1996. 


\section{THE THEME OF DAEDALUS AND ICARUS IN EUROPEAN LITERATURE}

Keywords: thematology, Daedalus, Icarus, European literature, Slovene literature, literary-historical overview

\section{Abstract}

The article deals with the recurrence of the theme of Daedalus and Icarus within European and Slovene literature. It is possible to discern common characteristics in this theme in literary works belonging to various historical periods. Thus in Antiquity authors generally emphasised the relationship between father and son in the mythological tale of Daedalus and Icarus; in the Middle Ages, the character of Icarus was mainly seen in a moralizing light, as an allegory of human vanity and conceit, while the Renaissance bestowed upon Icarus the role of a hero in love songs. In the period between Baudelaire and Joyce, both Icarus and Daedalus were primarily associated with the idea of the modern artist, who contemplates questions of life with great intensity, while the period after 1945 brought about new contextualizations of the mythological tale. Just as in the original mythological tale, subsequent literary portrayals of Daedalus and Icarus generally portray the two characters independently from one another. The difference between them manifests itself primarily through the contrast between youth and old age, and the contrast between the creative nature of poetry, on the one hand, which brings emotions to the fore, and science, on the other hand, which is based on reason. From this perspective, then, the character of Icarus is endowed with enthusiasm, ambition, courage, impetuosity, irrationality and sometimes even madness. He represents an extraordinary individual, who strives for an exalted ideal, which in turn becomes the very reason for his physical demise. He has an ambivalent nature: one can perceive him either as an arrogant figure or a hero. In contrast to Icarus, his father Daedalus is a skilled craftsman and artisan. He represents prudence, balance and reason, while striving for freedom of creation. In Slovene literature, a portrayal of the theme of Daedalus can be found in the poem of Janez Mihelič from the 
period of Enlightenment, while the character of Icarus appears in the title of one of Kosovel's poems. Later on, the theme is mainly treated by authors of the nineteen eighties. Thus, Vladimir Gajšek, by way of associations, enumerates the majority of known interpretations of the theme of Icarus; Tone Pavček relates to the character of Icarus through the theme of death and the memory of his dead son; Ciril Zlobec presents the identification of modern man with the negative aspects of the mythological hero's fate; while Drago Jančar, who deals with the theme of Daedalus and Icarus in two of his plays and one novel, characteristically associates the figures from Antiquity with actual historic characters. 